\title{
Cellular Physiology

\section{Sex Differences in Brown Adipose Tissue Thermogenic Features During Caloric Restriction}

\author{
Adamo Valle, Francisco J. García-Palmer, Jordi Oliver and Pilar \\ Roca
}

Grup de Metabolisme Energètic i Nutrició. Departament de Biologia Fonamental i Ciències de la Salut. Institut Universitari d'Investigació en Ciències de la Salut (IUNICS). Universitat de les Illes Balears, Palma de Mallorca

\section{Key Words \\ UCP1 - Adrenergic receptors - Mitochondria • OXPHOS}

\section{Abstract}

Caloric restriction (CR) studies have shown that females rats conserve energy more efficiently, showing a higher resistance to weight loss and higher protection of vital organs mass than male rats. Gender-dependent inactivation of thermogenesis in brown adipose tissue (BAT) has been proposed as one of these possible energy conserving mechanisms. To study the changes underlying this inactivation in rats, a three month study with $40 \%$ CR was undertaken to unravel the effects on BAT recruitment. Under ad libitum conditions female rats had greater BAT recruitment and greater oxygen consumption than their male counterparts. Total and mitochondrial protein, as well as triglyceride and DNA content were more reduced in restricted female rats than in restricted males. Similarly, the levels of key BAT functional proteins (UCP1, LPL, HSL, TFAM) were more reduced in restricted females, whereas no changes were found in mitochondrial DNA levels (mtDNA) and OXPHOS activities in males and females.
\end{abstract}

\section{KARGER}

Fax +41613061234

E-Mail karger@karger.ch

www.karger.com
(C) 2006 S. Karger AG, Basel

1015-8987/07/0194-0195\$23.50/0

Accessible online at:

www.karger.com/journals/net
Furthermore, $\alpha_{2 \mathrm{~A}} / \beta_{3}$ adrenergic receptor ratio remained constant in male rats whereas in female rats $\mathrm{CR}$ increased $60 \%$. In conclusion, our results suggest that female rats, whose BAT thermogenic activity is higher in ad libitum conditions, is depressed during CR. This inactivation involves the mitochondrial differentiation process and lipolytic system and could be due, at least in part, to the unfavourable adrenergic receptor balance for thermogenic activation.

Copyright @ 2007 S. Karger AG, Basel

\section{Introduction}

Brown adipose tissue (BAT) plays an important role in the regulation of energy balance since it is a major site of both cold- and diet-induced thermogenesis in small mammals. BAT thermogenic activity is dependent on its specific uncoupling protein 1 (UCP1), an inner membrane mitochondrial protein which dissipates energy as heat by uncoupling oxidative phosphorylation [1]. The main 
physiological regulator of BAT thermogenesis is norepinephrine, released by sympathetic terminals that densely innervate the tissue. Adrenergic stimulation promotes BAT thermogenic capacity or recruitment state activating UCP1 expression [2], increasing mitochondriogenesis [3], and promoting adipocyte proliferation [4]. Moreover, adrenergic stimulation increases intracellular free fatty acids, released by lipolysis, which directly activates UCP1 [5] and provides metabolic fuel for thermogenesis, suggesting that lipolysis is the fluxgenerating step controlling BAT activity [6]. Cathecolamine effects are mainly mediated by adrenergic receptors (ARs) present on adipocyte membrane [7]. The balance between the cellular content of $\alpha_{2}-\mathrm{AR}$ (inhibitor) and $\beta_{3}-\mathrm{AR}$ (activator) is central to the regulation of thermogenesis as it modulates the net adrenergic signal response in the adipocyte [8].

Caloric restriction (CR) is a condition in which enhanced energy dissipation would be disadvantageous. Periods of short food supply are often repeated in the wild, selecting organisms with more efficient mechanisms for energy metabolism. Some authors have argued that because their relative importance for reproduction and the survival of the species, females have been affected by natural selection pressures to be more resistant to CR than males [9]. It has been hypothetized that these energy conserving mechanisms in the females could be the same as those that give females a higher propensity for obesity under hypercaloric conditions [10,11]. The mechanisms involved in this gender-dependent adaptation of energy balance remain unclear.

Although the reduced energy expenditure which occurs during CR has been associated partly to a lower BAT activity [12], very few studies have looked for gender differences in BAT during CR. In previous works, we studied the effect of gender in the adaptation of energy metabolism to $\mathrm{CR}$ and our results pointed out that BAT may be involved in the gender differences found, with female rats showing a significant drop in UCP1 content [13]. In addition, gender differences in BAT have been also found in cold- and diet-induced thermogenesis [14, 15] suggesting a physiological importance for sexdependent regulation of BAT uncoupling activity. Taking this into account, the aim of this work was to investigate the gender-dependent changes underlying BAT inactivation during $\mathrm{CR}$, analyzing the effects on important parameters in the activity and control of BAT thermogenesis, i.e. tissue composition, mitochondrial recruitment, enzymes of lipid metabolism and adrenergic receptors.

\section{Materials and Methods}

\section{Materials}

Routine chemicals used were supplied by Sigma-Aldrich (St.Louise, USA), Panreac (Barcelona, Spain), Pronadisa (Madrid, Spain) and Amersham Pharmacia Biotech (Little Chalfont, UK). Oligonucleotide primer sequences were from Roche Diagnostics (Basel, Switzerland). Antibodies for $\alpha_{2}$-AR and $\beta_{3}$-AR were obtained from Santa Cruz Biotechnology (Calif., USA). Antibodies for HSL and TFAM were kindly supplied by Dr. F.B. Kraemer [16] and Dr. H. Inagaki [17], respectively. Antibody for LPL was previously developed in our laboratory [18]. Appropriate secondary antibodies were purchased from Sigma-Aldrich.

\section{Animals and diets}

All animals were treated in accordance with the university bioethical committee guidelines for animal care and EU regulations (86/609/EEC). 12 male and 12 female Wistar rats aged 60 days were purchased from Charles River (Barcelona, Spain) and housed individually in wire-bottomed cages at $22^{\circ} \mathrm{C}$ with $12 \mathrm{~h}$ light-dark cycle. To study the effects of CR in both genders, males and female rats were randomly divided into two dietary groups: ad libitum and caloric restricted. Ad libitum animals were fed with standard chow pellets (A04, supplied by Panlab, Barcelona, Spain) and restricted animals were fed for 100 days at the start of the dark cycle with $60 \%$ of the mean amount of diet consumed the previous week by the ad libitum group of the same gender.

\section{Indirect calorimetry}

Whole body oxygen consumption $\left(\mathrm{VO}_{2}\right)$ was measured by open-circuit respirometry in metabolic cages ventilated with fresh air at a rate of $1 \mathrm{~L} / \mathrm{min}$. Oxygen consumption was calculated from the difference in $\mathrm{O}_{2}$ concentration between inflow and outflow air using a differential $\mathrm{O}_{2}$ analyzer (Panlab). Animals were placed individually in the cages and acclimated for $1 \mathrm{~h}$. Data recordings were obtained during the last $2 \mathrm{~h}$ of the dark phase. Average $\mathrm{VO}_{2}$ was calculated from three repeated measures of each animal during the two weeks before sacrifice.

\section{$B A T$ collection and mitochondria isolation}

Animals were killed by decapitation at the start of the light phase. The interscapular BAT was excised, weighed and homogenized in isolation buffer $(250 \mathrm{mM}$ sucrose, $5 \mathrm{mM}$ Tris$\mathrm{HCl}, 2 \mathrm{mM}$ EGTA, $\mathrm{pH} 7.2,4^{\circ} \mathrm{C}$ ) in a Teflón/glass homogenizer. The homogenate was filtered through a layer of gauze. Aliquots were used for determination of total protein, DNA and triglycerides content as described elsewhere [19-21] and also cytochrome c activity and western blotting measurements (see below). The rest of the homogenate was used for isolation of mitochondria by differential centrifugation. The nuclei and cell debris were removed by centrifugation at $500 \mathrm{xg}$ for $10 \mathrm{~min}$. The supernatant was centrifuged at $8000 \mathrm{xg}$ to yield the mitochondrial pellet. The pellet was washed once by resuspension, centrifuged $(8000 \mathrm{xg})$ and the final pellet was resuspended in the same buffer. The gravitational force used was chosen in

Valle/García-Palmer/Oliver/Roca 
Fig. 1. Effect of CR on body mass, BAT weight and oxygen consumption. A: Body mass. B: BAT weight. C: Oxygen consumption rate adjusted por body mass ${ }^{0,75}\left(\mathrm{VO}_{2}\right)$. The data represent the means \pm SEM, from six animals per group. ANOVA $(p<0,05)$ : R, effect of diet; $G$, effect of gender; GxR, interaction of gender and diet. Student's t test $(\mathrm{p}<0,05) .{ }^{\circ}$ ad libitum vs. CR; * males vs. females.

order to achieve a representative fraction of whole mitochondrial population preserving integrity [22]. Mitochondrial protein was measured by the Bradford method.

\section{OXPHOS activities}

The measurement of the specific activities of the oxidative phosphorylation (OXPHOS) complexes (complex I (NADHubiquinone oxidoreductase; EC 1.6.99.5) [23], complex III (ubiquinol:cytochrome c reductase; EC 1.10.2.2) [24], complex IV or COX (cytochrome c oxidase; EC 1.9.3.1) [25], complex V or ATPase $\left(\mathrm{F}_{1} \mathrm{~F}_{0}\right.$-ATP synthase; EC 3.6.1.3) [23], were performed as described adapted to microtiter plate assay with some modifications. The assays were performed in $200 \mu 1$ final volume with $1-5 \mu \mathrm{g}$ mitochondrial proteins. COX activity was also measured in homogenate in order to calculate the mitochondrial recovery.

\section{Western blotting}

As described elsewhere [26], 15 $\mu \mathrm{g}$ mitochondrial protein for UCP1 and $20 \mu \mathrm{g}$ homogenate protein for ARs, LPL, and HSL were fractioned by SDS-PAGE [27] (12\% polyacrylamide for UCP1 and $10 \%$ for the rest of analysed proteins) and electrotransferred onto nitrocellulose filters. Ponceu S staining was used to provide visual evidence of correct loading and electrophoretic transfer of proteins to nitrocellulose filter. Membranes were incubated overnight at $4{ }^{\circ} \mathrm{C}$ in a blocking solution of 5\% non-fat powdered milk in T-PBS (phosphatebuffered saline, $\mathrm{pH} 7.5$, containing $0.1 \%$ Tween 20 ). Developments of the immunoblots were performed using an enhanced chemiluminiscence Western blotting analysis system (Amersham). Bands in films were analysed by scanner photodensitometry and quantified using Kodak 1D Image Analysis Software.

\section{Extraction and quantification of mitochondrial DNA}

Mitochondrial DNA (mtDNA) was extracted by digestion with proteinase $\mathrm{K}(100 \mu \mathrm{g} / \mu \mathrm{l})$ in a buffer containing $50 \mathrm{mM} \mathrm{KCl}$, $10 \mathrm{mM}$ Tris- $\mathrm{HCl}, 2.5 \mathrm{mM} \mathrm{MgCl}_{2}$ and $0.5 \%$ Tween 20 . Homogenate samples were incubated overnight at $37^{\circ} \mathrm{C}$ and then boiled for $5 \mathrm{~min}$ in order to inactivate the enzyme. Mitochondrial DNA was linearised by digestion with $\mathrm{Bcl} I$ restriction enzyme for $3 \mathrm{~h}$ at $50^{\circ} \mathrm{C}$ and boiled for $5 \mathrm{~min}$. Samples were centrifuged at $7000 \mathrm{xg}$ for $5 \mathrm{~min}$ and the resulting supernatant was used for amplification. A quantitative PCR assay was adapted to the LightCycler technology from Koekemoer et al [28]. PCR was performed to amplify a 162-nts fragment of the mitochondrial NADH dehydrogenase subunit 4 gene. The primer sequences were 5'-TAC ACG ATG AGG CAA CCAAA-3' and 5'-GGT AGG GGG TGT GTT GTG AG-3'. The concentration of the purified

Gender and Caloric Restriction Effects on BAT

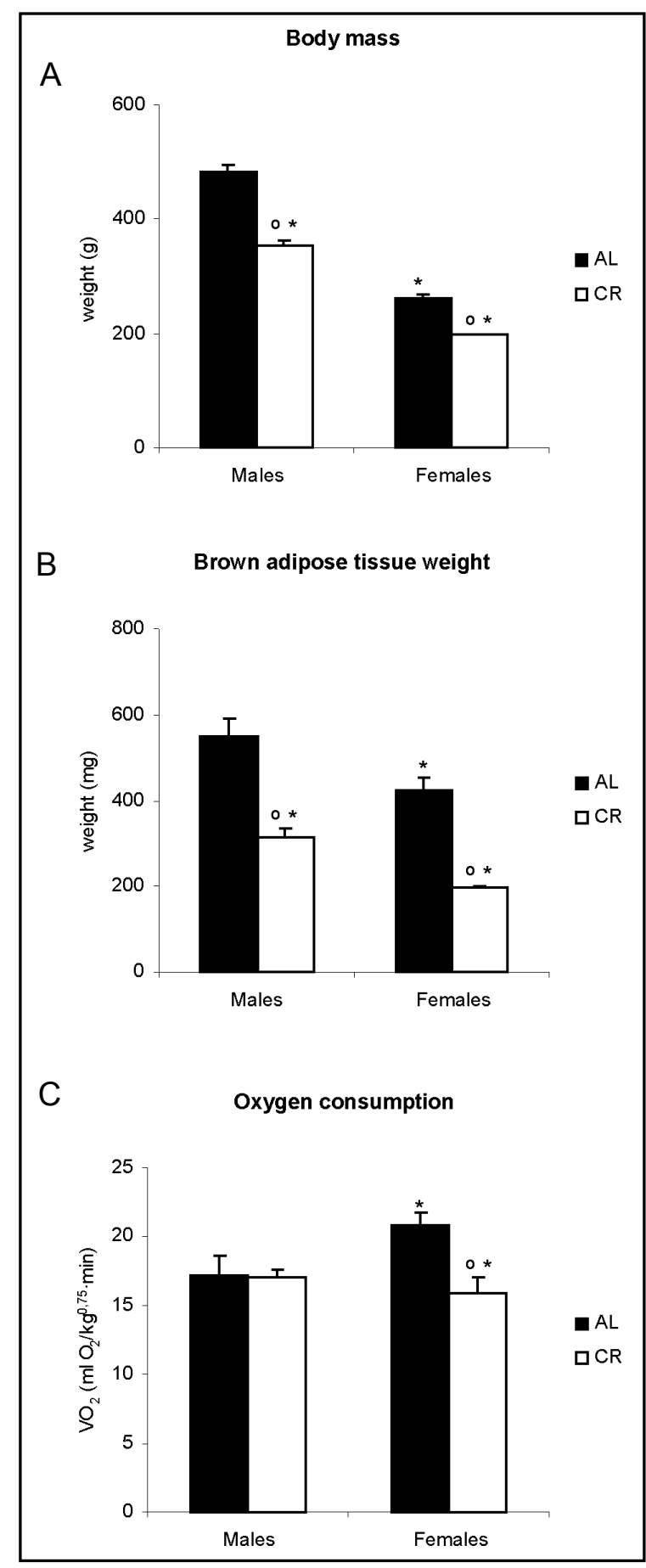

template was determined spectrophotometrically. Increasing amounts of template were amplified in parallel reactions to obtain a standard curve. Amplification was carried out in a LightCycler rapid thermal cycler system (Roche, Switzerland) using a total volume of $10 \mu \mathrm{l}$ containing $0.375 \mu \mathrm{M}$ of each primer, $3 \mathrm{mM} \mathrm{MgCl}$, $1 \mu 1$ LightCycler-FastStart DNA Master SYBR ${ }^{\mathrm{TM}}$ Green I (Roche, Switzerland) and $2.5 \mu 1$ of sample prepared as described above. The PCR reactions were cycled 35 times after initial denaturation $\left(95^{\circ} \mathrm{C}, 10 \mathrm{~min}\right)$, with the following parameters: denaturation at $95^{\circ} \mathrm{C}$ for $10 \mathrm{~s}$, annealing at $60^{\circ} \mathrm{C}$ for $12 \mathrm{~s}$, extension at $72^{\circ} \mathrm{C}$ for $12 \mathrm{~s}$.

Cell Physiol Biochem 2007;19:195-204 


\begin{tabular}{|c|c|c|c|c|c|}
\hline \multirow[b]{2}{*}{ Parameter } & \multicolumn{2}{|c|}{ MALES } & \multicolumn{2}{|c|}{ FEMALES } & \multirow[b]{2}{*}{ ANOVA } \\
\hline & Ad libitum & $40 \% \mathrm{CR}$ & Ad libitum & $40 \% \mathrm{CR}$ & \\
\hline \multicolumn{6}{|l|}{ DNA } \\
\hline $\mathrm{mg}$ DNA/g BAT & $1.88 \pm 0.20$ & $3.28 \pm 0.35$ & $2.53 \pm 0.10^{*}$ & $4.00 \pm 0.35^{\circ}$ & $\mathrm{R}$ \\
\hline $\mathrm{mg} / \mathrm{depot}$ & $1.04 \pm 0.05$ & $1.01 \pm 0.15$ & $1.07 \pm 0.05$ & $0.791 \pm 0.07$ & NS \\
\hline \multicolumn{6}{|l|}{ Triglyceride } \\
\hline $\mathrm{mg} / \mathrm{g}$ BAT & $246 \pm 69$ & $298 \pm 56$ & $533 \pm 71$ & $323 \pm 76$ & $\mathrm{G}$ \\
\hline $\mathrm{mg} / \mathrm{mg}$ DNA & $131 \pm 33$ & $91.2 \pm 14.8$ & $213 \pm 30$ & $76.9 \pm 13.6^{\circ}$ & $\mathrm{R}$ \\
\hline $\mathrm{mg} / \mathrm{depot}$ & $140 \pm 42$ & $88.1 \pm 12.7$ & $233 \pm 42$ & $63.9 \pm 15.2$ & $\mathrm{R}$ \\
\hline \multicolumn{6}{|l|}{ Protein } \\
\hline $\mathrm{mg} / \mathrm{g}$ BAT & $41.9 \pm 2.5$ & $68.0 \pm 7.3^{\circ}$ & $66.7 \pm 5.6^{*}$ & $80.8 \pm 9.5$ & G,R \\
\hline $\mathrm{mg} / \mathrm{mg}$ DNA & $22.9 \pm 1.7$ & $21.3 \pm 2.2$ & $26.3 \pm 2.5$ & $20.1 \pm 1.4^{\circ}$ & $\mathrm{R}$ \\
\hline $\mathrm{mg} / \mathrm{depot}$ & $23.7 \pm 2.0$ & $20.3 \pm 1.6$ & $29.4 \pm 3.3$ & $15.9 \pm 1.9^{\circ}$ & $\mathrm{R}, \mathrm{GxR}$ \\
\hline $\begin{array}{l}\text { Mitochondrial protein } \\
\mathrm{mg} / \mathrm{g} \text { BAT }\end{array}$ & $22.6 \pm 3.7$ & $54.9 \pm 16.0^{\circ}$ & $45.6 \pm 5.7^{*}$ & $57.5 \pm 15.6$ & NS \\
\hline $\mathrm{mg} / \mathrm{mg} \mathrm{DNA}$ & $12.1 \pm 1.6$ & $15.9 \pm 4.3$ & $18.8 \pm 2.6^{*}$ & $14.7 \pm 43$ & NS \\
\hline $\mathrm{mg} / \mathrm{depot}$ & $11.6 \pm 2.1$ & $12.7 \pm 3.2$ & $18.1 \pm 3.0$ & $10.1 \pm 2.7^{\mathrm{o}}$ & NS \\
\hline
\end{tabular}

Table 1. Effect of CR on BAT composition in male and female rats. The data represent the means \pm SEM, from six animals per group. ANOVA $(p<0,05)$ : R, effect of diet; $G$, effect of gender; GxR, interaction of gender and diet. Student's t test $(\mathrm{p}<0,05):{ }^{\circ} \mathrm{Ad}$ libitum vs. $\mathrm{CR} ;{ }^{*}$ males vs. females.

\section{Statistics}

The Statistical Program for the Social Sciences software for Windows (SPSS, Version 12.0) was employed for all statistical analyses. Data are presented as mean \pm SEM. Differences between groups were assessed by two-way analysis of variance (ANOVA) and Student's t-test. Statistical significance was set at $\mathrm{p}<0.05$.

\section{Results}

Body mass, BAT weight and respirometry

Figure 1A shows body mass of the four groups studied. CR decreased body mass in both genders. No significant differences were found in body mass loss between genders (26.5\% in males and $24.2 \%$ in females).

BAT weight is shown in Figure 1B. Althought BAT absolute weight was higher in males, ad libitum female rats had a greater BAT weight adjusted per body mass $(163 \mathrm{mg} / \mathrm{g})$ than males $(114 \mathrm{mg} / \mathrm{g})$. BAT weight was reduced $54 \%$ in females and $43 \%$ in males by $\mathrm{CR}$.

Oxygen consumption $\left(\mathrm{VO}_{2}\right)$ was higher in ad libitum fed female rats than in males (Fig 1C). $\mathrm{VO}_{2}$ was decreased by CR in the females, and neared those levels in males. Similar findings were obtained in previous works $[13,21]$.

\section{BAT composition}

To test whether the decrease in energy expenditure was related to impaired BAT thermogenesis, we decided to study the composition and recruitment features of BAT.
Table 1 shows the values of DNA, triglyceride and protein content in BAT. These parameters (per gram of tissue) have also been normalized to mg of DNA, to avoid the concentration effects of CR when data is normalized per gram, and per whole depot.

Ad libitum female rats showed higher triglyceride and protein contents than males, supporting the higher lipid multilocular arrangement and thermogenesis reported by other authors [21]. The higher loss of BAT weight produced by $\mathrm{CR}$ in the female in comparison to male rats was accompanied by a higher loss of triglyceride $(-63 \%$ vs. $-30 \%)$, protein $(-23 \%$ vs. $-7 \%)$ and total DNA ($26 \%$ vs. $-3 \%$, respectively), this latter indicating a significant decrease in cell number. These changes suggest that females, whose BAT seems to be active in ad libitum conditions, deactivate thermogenesis in a greater extent than males in response to CR. In agreement with this, whole mitochondrial protein (per depot) was higher in female than in male rats and it was decreased by CR in a gender-dependent way. This fact indicates that caloric restricted female rats displayed a lower mitochondrial protein content, which could be due to a lower mitochondria number and/or lower differentiation state of these mitochondria.

\section{Mitochondrial DNA and TFAM levels}

To test whether the lower mitochondrial protein content in restricted females was due to a decrease in mitochondrial number, we studied the mitochondrial DNA content (mtDNA). The levels of mtDNA could be a good

Valle/García-Palmer/Oliver/Roca 


\begin{tabular}{llllll}
\hline & \multicolumn{2}{c}{ MALES } & \multicolumn{2}{c}{ FEMALES } \\
Parameter & Ad libitum & $40 \% \mathrm{CR}$ & Ad libitum & $40 \% \mathrm{CR}$ & ANOVA \\
\hline mtDNA & & & & & \\
ng/g BAT & $44.1 \pm 16.1$ & $76.4 \pm 36.5$ & $35.2 \pm 3.4$ & $69.4 \pm 19.1$ & $\mathrm{NS}$ \\
ng/mg tDNA & $21.3 \pm 6.1$ & $22.1 \pm 9.5$ & $13.8 \pm 1.9$ & $17.2 \pm 3.9$ & $\mathrm{NS}$ \\
ng/mg mt protein & $6.04 \pm 2.48$ & $5.12 \pm 2.23$ & $2.62 \pm 0.23$ & $5.01 \pm 1.90^{\circ}$ & $\mathrm{NS}$ \\
TFAM & & & & & \\
a.u./mg mt protein & $100 \pm 14$ & $91.4 \pm 14.6$ & $92.2 \pm 21.8$ & $46.5 \pm 9.5^{\circ *}$ & $\mathrm{NS}$ \\
\hline
\end{tabular}

Table 2. Effect of CR on mtDNA and TFAM specific protein levels in BAT mitochondria of male and female rats. TFAM levels are expressed relative to levels found in AL male rats, which were set at $100 \%$ The data represent the means \pm SEM, from six animals per group. ANOVA $(p<0,05)$ : R, effect of restriction; $G$, effect of gender; GxR, interaction of gender and diet. Post hoc analisis Student's t test $(\mathrm{p}<0,05)$ : ${ }^{\circ}$ Ad libitum vs. CR; * males vs. females.

indicative parameter of mitochondrial number as there is a direct relationship between the number of mtDNA copies and the number of mitochondria [29-31]. As shown in table 2, restricted rats displayed higher mtDNA content adjusted per gram of tissue as a result of the concentrative effect of the fat loss induced by CR. This effect is avoided when data is adjusted per cellular DNA, showing restricted rats similar levels than ad libitum rats. Considering mtDNA indicative of mitochondria number, the number of mitochondria would not be affected by $\mathrm{CR}$, thus the lower mitochondrial protein would be due to the reduced protein content per mitochondria.

In order to evaluate the differentiation state of these mitochondrias, we examined the $\mathrm{mtDNA} / \mathrm{mtprotein}$ ratio and the mitochondrial transcription factor A (TFAM), a transcription factor involved in the expression of the proteins encoded by the mitochondrial genome [32]. The ad libitum fed female rats showed the lowest ratio mtDNA/mtprotein, indicating a tendency for a higher degree of maturation, which was in agreement with previous reports $[21,33]$. On the contrary, restricted female rats showed similar mtDNA/mtprotein ratio than males (which levels were not affected by CR).

As regards to TFAM levels, no differences were found between genders in ad libitum feeding conditions (all representative western blots are given in figure 2). However, the specific levels of this differentiation marker were dramatically decreased in restricted female rats. On the whole, these results support the notion of a lower differentiation state in mitochondria of restricted female rats rather than a lower mitochondrial pool.

\section{UCP1 content and mitochondrial OXPHOS activities}

BAT thermogenic function relies on its characteristic mitochondrial protein UCP1, which uncouples oxidative phosphorylation [34]. In order to assess the qualitative

Gender and Caloric Restriction Effects on BAT

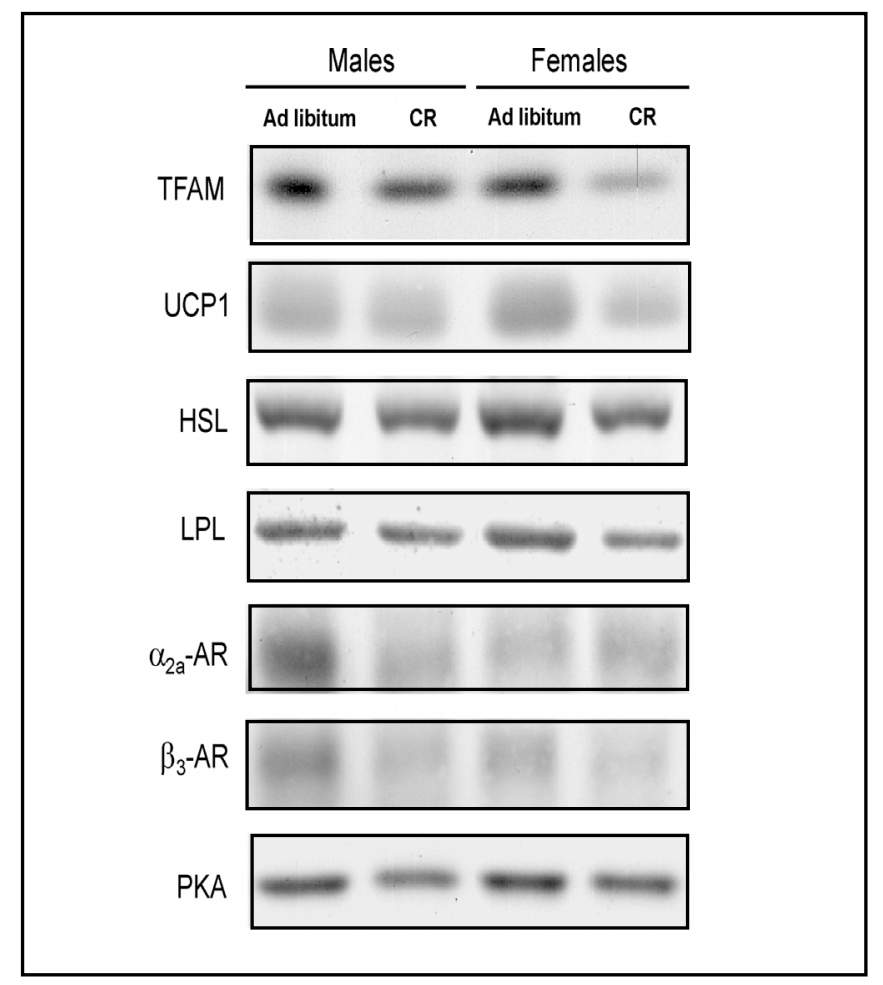

Fig. 2. Representative western blot of TFAM, UCP1, HSL, LPL, $\alpha_{2 \mathrm{~A}}$-AR, $\beta_{3}$-AR and PKA. $15 \mu \mathrm{g}$ of total protein was loaded for UCP1 and $20 \mu \mathrm{g}$ for TFAM, HSL, LPL, PKA. Developed western blot nitrocellulose membranes were exposed to Hyperfilm ECL (Amersham Biosciences), and representative bands in films are shown.

changes in mitochondrial thermogenic machinery we analyzed in detail the main components involved in the generation of the electro-chemical gradient and its dissipation as heat: the OXPHOS activities and the UCP1 content, respectively. As shown in Table 3, no differences were found in the specific activity of the four OXPHOS complex studied (I, III, IV and V). However, the specific UCP 1 content showed gender differences both in ad libitum and CR conditions. The ad libitum fed female

Cell Physiol Biochem 2007;19:195-204

199 


\begin{tabular}{|c|c|c|c|c|c|}
\hline \multirow[b]{2}{*}{ Parameter } & \multicolumn{2}{|c|}{ MAIES } & \multicolumn{2}{|c|}{ FEMALES } & \multirow[b]{2}{*}{ ANOVA } \\
\hline & Ad libitum & $40 \% \mathrm{CR}$ & Ad libitum & $40 \% \mathrm{CR}$ & \\
\hline $\begin{array}{l}\text { Complex I activity } \\
\text { IU/mg mitochondrial protein } \\
\text { Complex III activitv }\end{array}$ & $1.06 \pm 0.12$ & $0.77 \pm 0.11$ & $0.87 \pm 0.16$ & $1.03 \pm 0.20$ & NS \\
\hline $\begin{array}{l}\text { IU/mg mitochondrial protein } \\
\text { Complex IV activity }\end{array}$ & $11.6 \pm 0.9$ & $14.2 \pm 2.0$ & $11.8 \pm 1.8$ & $13.4 \pm 2.9$ & NS \\
\hline $\begin{array}{l}\text { a.u./mg mitochondrial protein } \\
\text { Complex V activity } \\
\mathrm{mIU} / \mathrm{mg} \text { mitochondrial protein } \\
\text { UCP1 }\end{array}$ & $\begin{array}{l}100 \pm 17 \\
1.37 \pm 0.17\end{array}$ & $\begin{array}{l}65.5 \pm 7.5 \\
0.96 \pm 0.05\end{array}$ & $\begin{array}{l}56.9 \pm 13.2 \\
1.14 \pm 0.13\end{array}$ & $\begin{array}{r}81 \pm 17.4 \\
1.09 \pm 0.11\end{array}$ & $\begin{array}{l}\text { NS } \\
\text { NS }\end{array}$ \\
\hline$\%$ a.u./mg mitochondrial protein & $100 \pm 8$ & $120 \pm 15$ & $130 \pm 11 *$ & $97.6 \pm 12.1^{\circ}$ & GxR \\
\hline
\end{tabular}

Table 3. Effect of CR on mitochondrial OXPHOS activities and UCP1 specific protein level in BAT of male and female rats. Complex IV (COX) activity is expressed relative to activity found in AL male rats, which were set at $100 \%$ The data represent the means \pm SEM, from six animals per group. ANOVA $(p<0,05)$ : R, effect of diet; G, effect of gender; GxR, interaction of gender and diet. Student's t test $(\mathrm{p}<0,05)$ : ${ }^{\circ}$ Ad libitum vs. CR; * males vs. females.

rats showed higher UCP1 levels than males. CR produced a significant decrease (-30\%) in UCP1 levels of female rats, whereas the changes in restricted male rats (a $20 \%$ increase) were not statistically significant.

Since BAT implies an important component of energy expenditure, we decided correlationate the changes in the $\mathrm{VO}_{2}$ with the variation in the levels of UCP1 in whole BAT [34]. $\mathrm{VO}_{2}$ and UCP1 per depot showed a higher correlation coefficient in females $\left(\mathrm{r}^{2}=0.72\right)$ than in males $\left(\mathrm{r}^{2}=0.03\right)$. The close relationship between UCP1 and energy expenditure suggest that thermogenesis might be activated in female rats under usual housekeeping conditions and is switched off when the females are faced with low caloric intake.

Lipoprotein lipase and hormone-sensitive lipase Since fatty acids are modulators and metabolic fuel for thermogenesis, we studied the levels of the main enzymes involved in BAT fatty acid metabolism: lipoprotein lipase (LPL) and hormone-sensitive lipase (HSL). These enzymes play a key role in the control of lipolytic capacity in brown adipocytes, catalyzing the limiting steps in fatty acid uptake and use, respectively. As shown in table 4, the LPL levels were decreased by $\mathrm{CR}$ in both genders. This drop was greater in female rats $(-36 \%)$ than in males $(-20 \%)$, indicating that CR decreases to a larger extent, the capacity for fatty acid captation in the BAT of female rats.

For HSL no significant differences were found, although ad libitum female rats showed higher HSL content than ad libitum males. CR also produced a significant drop in the HSL content per mg of DNA in female rats $(-15 \%)$ whereas this effect was negligible in males. These gender related changes are greater when the loss in whole tissue is taken into account. Thus, female rats decreased $62 \%$ LPL and 57\% HSL content per depot versus respective $42 \%$ and $31 \%$ in males, which might have systemic implications in the fatty acid clearance. Taking this all together, these results suggest that in female rats CR decreases in a greater extent the capacity of BAT to uptake and oxidize fatty acids, the main thermogenic fuel.

\section{Adrenergic receptor levels}

In view of the changes found in lipolytic and thermogenic capacity, we decided to examine the levels of the main adrenergic receptors, $\alpha_{2 \mathrm{~A}}$ and $\beta_{3}$. The $\alpha_{2 \mathrm{~A}} /$ $\beta_{3}$ balance is key in the regulation of thermogenesis and lipolysis by modulating the net adrenergic signal response in the adipocyte. It has been established that a higher $\alpha_{2 \mathrm{~A}} / \beta_{3}$ would lead to a lower lipolytic and thermogenic activity and vice versa $[15,35,36]$. Ad libitum female rats showed lower values in both adrenoceptor levels as well as lower $\alpha_{2 \mathrm{~A}} / \beta_{3}$ ratio, although these differences did not reach statistical significance $(p=0.057)$. CR was found to induce a statistically significant reduction in the levels of the stimulatory $\beta_{3}$-AR in both genders. This drop in $\beta_{3}$-AR was higher in female rats, reaching a $50 \%$ decrease vs. $38 \%$ in males when normalized per mg of DNA. On the contrary, $\alpha_{2 \mathrm{~A}}-\mathrm{AR}$ was found to be reduced only in males, as restricted females had the same levels of their ad libitum counterparts. As a result, female rats went from the lowest $\alpha_{2 \mathrm{~A}} / \beta_{3}$ ratio under $a d$ libitum feeding conditions to the highest ratio under $\mathrm{CR}$,

Valle/García-Palmer/Oliver/Roca 


\begin{tabular}{llllll}
\hline & \multicolumn{2}{c}{ MALES } & \multicolumn{2}{c}{ FEMALES } & \\
Parameter & Ad libitum & $40 \%$ CR & Ad libitum & $40 \%$ CR & ANOVA \\
\hline LPL & & & & & \\
$\quad \%$ a.u./mg protein & $100 \pm 8$ & $79.9 \pm 8.0$ & $106 \pm 5$ & $68.1 \pm 2.5^{\circ}$ & $\mathrm{R}$ \\
\% a.u/mg DNA & $100 \pm 12$ & $75.2 \pm 12.6$ & $116 \pm 12$ & $58.0 \pm 5.2^{\circ}$ & $\mathrm{R}$ \\
\% a.u/depot & $100 \pm 11$ & $57.8 \pm 8.4^{\circ}$ & $118 \pm 14$ & $44.1 \pm 6.4^{\circ}$ & $\mathrm{R}$ \\
HSL & $100 \pm 18$ & $97.6 \pm 15.3$ & $146 \pm 23$ & $123 \pm 4$ & $\mathrm{NS}$ \\
\% a.u./mg protein & $100 \pm 21$ & $92.1 \pm 19.7$ & $161 \pm 28$ & $90.1 \pm 15.5^{\circ}$ & $\mathrm{R}$ \\
\% a.u/mg DNA & $100 \pm 22$ & $69.0 \pm 13.2$ & $160 \pm 27$ & $68.1 \pm 14.0^{\circ}$ & $\mathrm{R}$ \\
\% a.u/depot & $1.00 \pm 0.19$ & $0.79 \pm 0.13$ & $0.75 \pm 0.14$ & $0.50 \pm 0.03 *$ & $\mathrm{NS}$ \\
\hline ratio LPL/HSL &
\end{tabular}

Table 4. Effect of CR on LPL and HSL protein levels in BAT of male and female rats. Levels are expressed relative to AL male rat levels, which were set at $100 \%$ The data represent the means $\pm \mathrm{SEM}$, from six animals per group. ANOVA $(\mathrm{p}<0,05)$ : R, effect of diet; $\mathrm{G}$, effect of gender; GxR, interaction of gender and diet. Student's t test $(\mathrm{p}<0,05):{ }^{\circ}$ Ad libitum vs. CR; * males vs. females.

\begin{tabular}{|c|c|c|c|c|c|}
\hline \multirow[b]{2}{*}{ Parameter } & \multicolumn{2}{|c|}{ MALES } & \multicolumn{2}{|c|}{ FEMALES } & \multirow[b]{2}{*}{ ANOVA } \\
\hline & Ad libitum & $40 \% \mathrm{CR}$ & Ad libitum & $40 \% \mathrm{CR}$ & \\
\hline $\begin{array}{l}\beta_{3}-\mathrm{AR} \\
\% \text { a.u./mg protein }\end{array}$ & $100 \pm 9$ & $63.2 \pm 8.6$ & $78.9 \pm 10.0$ & $49.3 \pm 11.5$ & $\mathrm{R}$ \\
\hline $\begin{array}{l}\% \text { a.u/mg DNA } \\
\alpha_{2 \mathrm{~A}-\mathrm{AR}}\end{array}$ & $100 \pm 5$ & $61.8 \pm 14.4$ & $89.6 \pm 13.7$ & $43.8 \pm 15.2$ & $\mathrm{R}$ \\
\hline $\begin{array}{l}\% \text { a.u./mg protein } \\
\% \text { a.u } / \mathrm{mg} \text { DNA }\end{array}$ & $\begin{array}{l}100 \pm 10 \\
100 \pm 9\end{array}$ & $\begin{array}{l}64.5 \pm 16.2 \\
60.2 \pm 19.7\end{array}$ & $\begin{array}{l}67.7 \pm 10.5 \\
77.6 \pm 14.3\end{array}$ & $\begin{aligned} 68.8 & \pm 16.0 \\
61.1 & \pm 21.2\end{aligned}$ & $\begin{array}{l}\text { NS } \\
\text { NS }\end{array}$ \\
\hline $\begin{array}{l}\text { ratio } \alpha_{2 \AA} / \beta_{3}-A R \\
\text { PKA }\end{array}$ & $1.00 \pm 0.09$ & $0.92 \pm 0.13$ & $0.87 \pm 0.11$ & $1.39 \pm 0.03^{\circ \%}$ & GxR \\
\hline$\%$ a.u./mg protein & $100 \pm 6$ & $63.0 \pm 3.4^{\circ}$ & $137 \pm 8 *$ & $133 \pm 16^{*}$ & G \\
\hline$\%$ a.u/mg DNA & $100 \pm 11$ & $57.9 \pm 4.8$ & $151 \pm 18$ & $111 \pm 19$ & G,R \\
\hline
\end{tabular}

Table 5. Effect of CR on $\beta_{3}-\mathrm{AR}, \alpha_{2 \mathrm{~A}}$-AR and PKA protein levels in BAT of male and female rats. Levels are expressed relative to AL male rat levels, which were set at $100 \%$ The data represent the means $\pm \mathrm{SEM}$, from six animals per group. ANOVA $(\mathrm{p}<0,05)$ : R, effect of diet; $\mathrm{G}$, effect of gender; GxR, interaction of gender and diet. Student's t test $(\mathrm{p}<0,05):{ }^{\circ} \mathrm{Ad}$ libitum vs. $\mathrm{CR} ;{ }^{*}$ males vs. females.

whereas in male rats the ratio was kept constant by decreasing both subtypes of receptors in the same extent. The receptor profile in restricted female rats is aimed at inhibiting the lipolysis and thermogenesis and may be related, at least in part, to the impaired thermogenic features above mentioned.

\section{Discussion}

In this work we analyzed the effect of CR on the recruitment features and the levels of key proteins implicated in the control of the thermogenic and lipoliytic pathway in BAT of male and female rats.

Ad libitum fed female rats at $22^{\circ} \mathrm{C}$ had greater thermogenic capacity and activity than males, with a higher UCP1 content, higher total and mitochondrial protein content, and greater BAT size and cell number (both in

Gender and Caloric Restriction Effects on BAT relation to body weight). These findings are in agreement with previous works showing greater recruitment in BAT of female rats [21, 33]. In particular, it has been shown that ad libitum female rats have larger mitochondria, with longer cristae and higher cristae density [21]. These gender dimorphisms in mitochondria have been related to differences in the distribution pattern of mitochondria subpopulations, with females showing a highly differentiated mitochondrial pool than males [33]. One of the causes for these gender differences in BAT thermogenic capacity may be explained by the action of sex steroid hormones, which have shown to exert effects even at mitochondrial level [37]. Thus, ovariectomy in rats leads to an increase in energy gain, which can be prevented or reversed by estrogens $[38,39]$, whereas in male rats castration causes a reduction in energy gain [40]. Part of the estrogen effects on energy expenditure are mediated by changes in BAT thermogenesis [41, 42],

Cell Physiol Biochem 2007;19:195-204 201 
although mechanisms based on alterations in food intake and activity cannot be ruled out.

Male and female rats have different response to CR, with females showing a higher loss of recruitment features than male rats. This deactivation was characterized by a considerable decrease in BAT size, cell number, fat and protein content (both mitochondrial and total) when restricted are compared to ad libitum. However, in this loss of thermogenic capacity, no decrease in mitochondria number was found as is pointed out by our mtDNA results. Mitochondria from restricted female rats showed lower specific levels of the main thermogenic effector UCP1, whereas no changes were found for the rest of the OXPHOS complexes studied. This profile is indicative of a lesser differentiated mitochondria pool, since differentiation process has been shown to increase UCP1 levels to a greater extent than the electron transport chain complexes in BAT [33]. The ratio of mtDNA/ mtprotein suggests that mitochondria in female rats shifted from the highest maturation state in the ad libitum conditions to state similar to that of the male rats in CR, which has been shown to have a lower degree of functional differentiation in this tissue [33]. In agreement with this, specific TFAM levels, another mitochondrial differentiation marker used in this study, was found to be lower in restricted female rats. TFAM is necessary for mtDNA transcription and it has a concentration-dependent function, showing higher binding affinity for the mtDNA light strand promoter than for the heavy strand one, which encodes most of the mitochondrial proteins [32, 43]. Thus, TFAM/mtDNA ratio has been considered as a good indicative parameter of mitochondrial differentiation [44, 45]. Ad libitum fed female rats showed 2-fold higher ratio than ad libitum or restricted males (35.2 vs 16.5 and 17.8 respectively), supporting the notion of higher recruitment/differentiation state, whereas restricted females showed a $70 \%$ lesser ratio than ad libitum females (9.3). On the whole, the levels of TFAM, UCP1, mtDNA and mitochondrial protein suggest that female rats change their mitochondrial differentiation process under CR, showing a lesser differentiated mitochondria pool than in ad libitum conditions, likely without affecting mitochondrial proliferation process.

From a physiologic point of view, the lower thermogenic capacity in the restricted female rats is even greater since BAT showed a net diminution of cells in the tissue (total DNA content). Thus in female rats, the total amount of UCP1 protein per BAT depot (per animal), which encompasses both the levels of UCP1 in mitochondria and the effect of cell proliferation or apoptosis in the tissue [34], was found to be well correlated with the $\mathrm{VO}_{2}$, suggesting that the drop in UCP1 could be responsible for a decrease in energy expenditure in this gender.

Furthermore, restricted female rats showed higher depletion than males in the content of fatty acids, the main thermogenic fuel, indicating a lesser substrate availability for thermogenesis. These differences in fat content could be explained, at least in part, by the greater decrease in the levels of LPL found in the restricted female in comparison to the males. The decrease in LPL and HSL suggest a loss in fatty acid metabolic capacity in the BAT, which could be determined by the decreased insulin signalling [46]. Previous studies with CR rats have shown that females preserve lean mass to a greater degree than male rats by utilizing relatively more fat for energy needs [10]. From a systemic point of view, the lesser uptake capacity in BAT of restricted female rats could leave these energy dense fuels available for other tissues, permitting their use for purposes more profitable for survival.

As mentioned previously, the $\alpha_{2 \mathrm{~A}} / \beta_{3}$-AR balance is key in the regulation of thermogenesis and lipolysis in BAT by modulating the net adrenergic signal response [8]. Taking into account that the inhibitory $\alpha_{2 \mathrm{~A}}$-AR has the greatest affinity for cathecolamines, the higher ratio $\alpha_{2 \mathrm{~A}} / \beta_{3}-\mathrm{AR}$ in restricted females could mean a higher cathecolamine threshold to trigger the thermogenic and lipolytic response. In addition, it is known that adrenergic stimulation in BAT is decreased during food restriction [47]. Therefore under in vivo conditions it is probable that BAT thermogenic activity in restricted female rats would be very low, as it would be depressed at signal and receptor level. Bartness and Wade demonstrated that the BAT and its sympathetic innervation are very important for the estrogen mediated changes in energy expenditure [41]. In agreement with this, several in vivo and in vitro studies have reported that sex hormones modify the lipolytic and thermogenic signal by changing the responsiveness and/or density of $\beta$ - and $\alpha_{2 A}$-AR in the adipocyte $[42,48] . \alpha_{2 \mathrm{~A}}$-AR has been found to be upregulated by testosterone in cultured brown adipocytes, whereas female sex hormones (17 $\beta$-estradiol and progesterone) up-regulate $\beta_{3}$-AR and down-regulate $\alpha_{2 A}{ }^{-}$ AR, resulting in a lower $\alpha_{2 \mathrm{~A}} / \beta_{3}$-AR protein ratio $[49,50]$. Taking into account these findings, our results suggest the existence of a cross-talk between the CR signals and sex hormones probably at adrenergic receptor level.

Studies of wild animals suggest that stored body fat is regulated under stabilizing selection as part of a dynamic

Valle/García-Palmer/Oliver/Roca 
tradeoff between the risks of starvation, which promote fat storage, and the risks of predation, which promote leanness $[51,52]$. In this evolutionary scenario, BAT may have provided a powerful mechanism to regulate energy expenditure [34, 53]. Because of their extended role as caretakers for the young, as well as their obvious role during pregnancy and lactation, females with more favourable mechanisms for coping with food scarcity would been more apt to survive and produce more offspring, promoting the survival of the species $[9,11$, 54]. Supporting this notion are the findings reported here, with females showing a higher thermogenesis in ad libitum conditions in order to avoid excessive weight gain, and switching off this mechanism in order to economize energy when food is limited. This deactivation takes place at different levels of control of BAT activity, affecting cell number, mitochondrial machinery and fatty acid supplying system. Adrenergic receptor balance appears as candidate point, mediating the cross-talking between sex hormones and adrenergic stimuli in the genderdependent response to caloric restriction.

\section{Abbreviations}

CR (caloric restriction); BAT (interscapular brown adipose tissue); UCP1 (uncoupling protein 1); ARs (adrenergic receptors); OXPHOS (oxidative phosphorylation system); LPL (lipoprotein lipase); HSL (hormone-sensitive lipase); COX (cytochrome c oxidase); $\mathrm{VO}_{2}$ (oxygen consumption volume); mtDNA (mitochondrial DNA).

\section{Acknowledgements}

This investigation was supported by Conselleria d'Innovació i Energia de la Comunitat Autónoma de les Illes Balears (PRDIB-2002GC4-24) and by Fondo de Investigaciones Sanitarias (PI021339, PI042294 and PI042377) of the Spanish Government. A. Valle was funded by a grant from the Ministerio de Educación Cultura y Deporte of the Spanish Government.

\section{References}

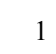

Ricquier D, Bouillaud F: Mitochondrial uncoupling proteins: from mitochondria to the regulation of energy balance. J Physiol 2000;529:3-10.

$\checkmark 2$ Nedergaard J, Golozoubova V, Matthias A, Asadi A, Jacobsson A, Cannon B: UCP1: the only protein able to mediate adaptive non-shivering thermogenesis and metabolic inefficiency. Biochim Biophys Acta 2001;1504:82-106.

-3 Herron D, Rehnmark S, Nechad M, Loncar D, Cannon B, Nedergaard J: Norepinephrine-induced synthesis of the uncoupling protein thermogenin (UCP) and its mitochondrial targeting in brown adipocytes differentiated in culture. FEBS Lett 1990;268:296-300.

$\checkmark 4$ Valladares A, Porras A, Alvarez AM, Roncero C, Benito M: Noradrenaline induces brown adipocytes cell growth via beta-receptors by a mechanism dependent on ERKs but independent of cAMP and PKA. J Cell Physiol 2000;185:324-30.

$\checkmark 5$ Rial E, Gonzalez-Barroso M, Fleury C, Iturrizaga S, Sanchis D, Jimenez-Jimenez J, Ricquier D, Goubern M, Bouillaud F: Retinoids activate proton transport by the uncoupling proteins UCP1 and UCP2. Embo J 1999;18(21):5827-33.

Atgie, C, D'Allaire F, Bukowiecki LJ: Role of beta1- and beta3-adrenoceptors in the regulation of lipolysis and thermogenesis in rat brown adipocytes. Am J Physiol 1997;273:C1136-42.
Lafontan M, Barbe P, Galitzky J, Tavernier G, Langin D, Carpene C, Bousquet-Melou A, Berlan M: Adrenergic regulation of adipocyte metabolism. Hum Reprod 1997;12 Suppl 1:6-20.

Valet P, Grujic D, Wade J, Ito M, Zingaretti MC, Soloveva V, Ross SR, Graves RA, Cinti S, Lafontan M, Lowell BB: Expression of human alpha 2adrenergic receptors in adipose tissue of beta 3-adrenergic receptor-deficient mice promotes diet-induced obesity. J Biol Chem 2000;275:34797-802.

Widdowson EM: The response of the sexes to nutritional stress. Proc Nutr Soc 1976;35:175-80.

10 Hill, J O, Talano C M, Nickel M, DiGirolamo $\mathrm{M}$ : Energy utilization in food-restricted female rats $J$ Nutr 1986;116: 2000-12.

Cortright RN, Koves TR: Sex differences in substrate metabolism and energy homeostasis. Can J Appl Physiol 2000;25:288-311.

12 Rothwell NJ, Stock MJ: Effect of chronic food restriction on energy balance, thermogenic capacity, and brownadipose-tissue activity in the rat. Biosci Rep 1982;2:543-9.

13 Valle A, Català-Niell A, Colom B, GarcíaPalmer F J, Oliver J, Roca P: Sex-related differences in energy balance in response to caloric restriction Am J Physiol Endocrinol Metab 2005;289:E15-22.
14 Quevedo S, Roca P, PicóC, Palou A: Sexassociated differences in cold-induced UCP1 synthesis in rodent brown adipose tissue Pfluge Arch 1998;436:689-95.

15 Roca P, Rodriguez A M, Oliver P, Bonet M L, Quevedo S, Picó C, Palou A: Brown adipose tissue response to cafeteria dietfeeding involves induction of the UCP2 gene and is impaired in female rats as compared to males Pflugers Arch 1999;438:628-34.

16 Kraemer F B, Patel S, Saedi M S, Sztalryd $\mathrm{C}$ : Detection of hormone-sensitive lipase in various tissues I. Expression of an HSL/ bacterial fusion protein and generation of anti-HSL antibodies J Lipid Res 1993;34:663-71.

17 Inagaki H, Hayashi T, Matsushima Y, Lin KH, Maeda S, Ichihara S, Kitagawa Y, Saito T: Isolation of rat mitochondrial transcription factor A (r-Tfam) cDNA. DNA Seq 2000;11:131-5.

Llado I, Pons A, Palou A: Effects of fasting on lipoprotein lipase activity in different depots of white and brown adipose tissues in diet-induced overweight rats. J Nutr Biochem 1999;10:609-14.

Bradford MM: A rapid and sensitive method for the quantitation of microgram quantities of protein utilizing the principle of protein-dye binding. Anal Biochem 1976;72:248-54. 
20 Thomas PS, Farquhar MN: Specific measurement of DNA in nuclei and nucleic acids using diaminobenzoic acid. Anal Biochem 1978,89:35-44.

21 Rodriguez-Cuenca S, Pujol E, Justo R, Frontera M, Oliver J, Gianotti M, Roca P: Sex-dependent thermogenesis differences in mitochondrial morphology and function and adrenergic response in brown adipose tissue $\mathrm{J}$ Biol Chem 2002;277:42958-63.

$>22$ Justo R, Oliver J, Gianotti M: Brown adipose tissue mitochondrial $>32$ subpopulations show different morphological and thermogenic characteristics. Mitochondrion 2005,5:45-53.

23 Ragan CI, Wilson MT, Darley-Usmar VM, Lowe PN: Subfractionation of mitochondria and isolation of the proteins of oxidative phosphorylation. In: Darley-Usmar VM, Rickwood D, Wilson MT (eds):Mitochondria, a practical approach. IRL Press, Oxford, 1987, pp 79-112.

24 Krahenbuhl S, Chang M, Brass EP, Hoppel CL: Decreased activities of ubiquinol ferricytochrome c oxidoreductase (complex III) and ferrocytochrome c oxygen oxidoreductase (complex IV) in liver mitochondria from rats with hydroxycobalamin[c-lactam]-induced methylmalonic aciduria $\mathrm{J}$ Biol Chem 1991;266:20998-1003.

-25 Chrzanowska-Lightowlers ZM, Turnbull DM, Lightowlers RN: A microtiter plate assay for cytochrome c oxidase in permeabilized whole cells. Anal Biochem 1993,214:45-9.

26 Krahenbuhl S, Chang M, Brass EP, Hoppel CL: Evidence for masking of brown adipose tissue mitochondrial GDPbinding sites in response to fasting in rats made obese by dietary manipulation. Effects of reversion to standard diet. Biochem J 1991;279:575-9.

27 Laemmli UK: Cleavage of structural proteins during the assembly of the head of bacteriophage T4. Nature 38 1970;227:680-5.

$>28$ Koekemoer TC, Downing TG, Oelofsen W: An alternative PCR assay for quantifying mitochondrial DNA in crude 39 preparations. Nucleic Acids Res 1998;26:2829-30.

Djouadi F, Bastin J, Gilbert T, Rotig A, 40 Rustin $\mathrm{P}$, Merlet-Benichou C: Mitochondrial biogenesis and development of respiratory chain enzymes in kidney cells: role of 41 glucocorticoids. Am J Physiol 1994;267:C245-54.
Ostronoff LK, Izquierdo JM, Enriquez JA, Montoya J, Cuezva JM: Transient activation of mitochondrial translation regulates the expression of the mitochondrial genome during mammalian mitochondrial differentiation.
1996;316:183-91.

Biochem

$\mathrm{J}$

Koekemoer TC, Oelofsen W: Properties of porcine white adipose tissue and liver mitochondrial subpopulations. Int $\mathrm{J}$ Biochem Cell Biol 2001,33(9):889-901. Garstka HL, Facke M, Escribano JR, Wiesner RJ: Stoichiometry of mitochondrial transcripts and regulation of gene expression by mitochondrial transcription factor A. Biochem Biophys Res Commun 1994;200:619-26.

Justo R, Frontera M, Pujol E, RodriguezCuenca S, Llado I, Garcia-Palmer FJ, Roca P, Gianotti M: Gender-related differences in morphology and thermogenic capacity of brown adipose tissue mitochondrial subpopulations. Life Sci 2005;76:1147-58.

34 Cannon B, Nedergaard J: Brown adipose tissue: function and physiological significance. Physiol Rev 2004,84:277359.

-35 Rodriguez F, Monjo M, Rodriguez-Cuenca S, Pujol E, Amengual B, Roca P, Palou A: Sexual dimorphism in the adrenergic control of rat brown adipose tissue response to overfeeding. Pflugers Arch 2001;442:396-403.

36 Pirke KM, Broocks A, Wilckens T, Marquard R, Schweiger U: Starvationinduced hyperactivity in the rat: the role $>49$ of endocrine and neurotransmitter changes. Neurosci Biobehav Rev 1993;17:287-94.

37 Chen JQ, Yager JD, Russo J: Regulation of mitochondrial respiratory chain structure and function by estrogens/ estrogen receptors and potential physiological/pathophysiological implications. Biochim Biophys Acta 2005;1746:1-17.

Richard D: Effects of ovarian hormones on energy balance and brown adipose tissue thermogenesis. Am J Physiol 1986;250:R245-9.

Wade GN, Gray JM, Bartness TJ: Gonadal influences on adiposity. Int J Obes 1985;9 $>52$ Suppl 1:83-92.

Rivest S, Landry J, Richard D: Effect of exercise training on energy balance of orchidectomized rats. Am J Physiol 53 1989;257:R550-5.

Bartness TJ, Wade GN: Effects of interscapular brown adipose tissue denervation on body weight and energy metabolism in ovariectomized and estradiol-treated rats. Behav Neurosci 1984;98:674-85.
Pedersen SB, Bruun JM, Kristensen K, Richelsen B: Regulation of UCP1, UCP2, and UCP3 mRNA expression in brown adipose tissue, white adipose tissue, and skeletal muscle in rats by estrogen. Biochem Biophys Res Commun 2001;288:191-7.

43 Fernandez-Silva P, Enriquez JA, Montoya $\mathrm{J}$ : Replication and transcription of mammalian mitochondrial DNA. Exp Physiol 2003,88:41-56.

Falkenberg M, Gaspari M, Rantanen A, Trifunovic A, Larsson NG, Gustafsson CM: Mitochondrial transcription factors B1 and B2 activate transcription of human mtDNA. Nat Genet 2002;31:289-94.

Alcolea MP, Colom B, Llado I, Gianotti M, Garcia-Palmer FJ: Mitochondrial transcription factor A (TFAM) is increased in rat embryo during placentation and associated with mitochondrial differentiation. Cell Physiol Biochem 2006;17:79-88.

Carneheim CM, Alexson SE: Refeeding and insulin increase lipoprotein lipase activity in rat brown adipose tissue. Am J Physiol 1989;256:E645-50.

47 Young JB, Saville E, Rothwell NJ, Stock MJ, Landsberg L: Effect of diet and cold exposure on norepinephrine turnover in brown adipose tissue of the rat. J Clin Invest 1982;69:1061-71.

Abelenda M, PuertaM: Dual control of cytochrome-c oxidase activity by female sex steroids. Eur J Endocrinol 1999;141:630-6.

Rodriguez AM, Monjo M, Roca P, Palou A: Opposite actions of testosterone and progesterone on UCP1 mRNA expression in cultured brown adipocytes. Cell Mol Life Sci 2002;59:1714-23.

Monjo M, Rodriguez AM, Palou A, Roca P: Direct effects of testosterone, 17 betaestradiol, and progesterone on adrenergic regulation in cultured brown adipocytes: potential mechanism for genderdependent thermogenesis. Endocrinology 2003;144:4923-30.

Gentle LK, Gosler AG: Fat reserves and perceived predation risk in the great tit, Parus major. Proc Biol Sci 2001;268:48791.

Pravosudov VV, Grubb TC: Management of fat reserves in tufted titmice Baelophus bicolor in relation to risk of predation. Anim Behav 1998;56:49-54.

Rothwell NJ, Stock MJ: A role for brown adipose tissue in diet-induced thermogenesis. Obes Res 1997;5:650-6. Hoyenga KB, Hoyenga KT: Gender and energy balance: sex differences in adaptations for feast and famine. Physiol Behav 1982;28:545-63. 